\title{
Facies, Sedimentary Environment and Sequence Stratigraphy of Dalan Formation in South Fars, Iran
}

\section{-(Qatar-South Fars Arch) Well ASL-A}

\author{
Nasser Rezavand ${ }^{1}$, Davood Jahani' ${ }^{1}$, Hossein Asilian² \\ ${ }^{1}$ Department of Geology, North Tehran Branch, Islamic Azad University, Tehran, Iran \\ ${ }^{2}$ Department of Stratigraphy and Sedimentology, NIOC Exploration, Tehran, Iran \\ Email: "Rezavand_n@yahoo.com
}

Received 6 July 2016; accepted 27 August 2016; published 30 August 2016

Copyright (C) 2016 by authors and Scientific Research Publishing Inc.

This work is licensed under the Creative Commons Attribution International License (CC BY).

http://creativecommons.org/licenses/by/4.0/

(c) (i) Open Access

\section{Abstract}

Dalan Formation is one of the most important gas reservoirs of south and southwest Iran which it belongs to Dehram Group and its age is Middle to Late Permian. The Dalan formation is interpreted as reflecting a major tectono-eustatic event related to the onset of rapid thermal subsidence of the early Neo-Tethys passive margin in Arabia and Iran, and the drowning of its rift shoulders. The Dalan formation consists mainly of medium to thick-bedded oolitic to micritic shallow-marine carbonate, with intercalations of evaporates. This formation overlies the Faraghan formation and extends up into the Lower Triassic kangan formation. The current paper is focused on the facies, sedimentary environment and sequence Stratigraphy study of the Middle to Upper Permian Dalan formation in the West Assaluyeh gas field the subsurface section of well ASL-A. Based on microfacies analysis and significant founa and flora, nineteen major facies in five facies associations including Tidal flat (A), Lagoon (B), Shoal (C), Open marine (D) and Mid ramp (E) were recognized in the Dalan formation. Facies analysis and those comparisons with modern and ancient environments indicated that the Dalan formation was deposited inner to mid parts of a homoclinal ramp. The sequence stratigraphy studies on the Dalan formation in this gas field led to assessment of seven main sedimentary sequences of the third-order in the Assaluyeh field, well ASL-A. The boundary between the third-order sequences with the Faraghan formation and between the Nar and Upper Dalan members are Subaerial Unconformity (SU) and the boundaries between the third-order sequences with each other and also with the Kangan formation are Correlative Conformity (CC). The main diagenetic processes in this formation are dolomitization, dissolution, anhydritization, cementation and compaction which played a significant role in improving reservoir quality. The shoal ooid grainstone facies with intergranular and oomoldic porosity

${ }^{*}$ Corresponding author. 
comprise the main reservoir facies of the Dalan formation.

Keywords

Facies, Sedimentary Environment, Homoclinal Ramp, Sequence Stratigraphy, Dalan Formation

\section{Introduction}

The hydrocarbon reservoirs of the Dalan formation in the Qatar-South Fars Arch contain some of the important gas reserves in the Middle East region, as well as the world [1] [2]. Stratigraphic cross section of the Dalan formation measured at Kuh-e-Faraghan is the thickest section of this formation in northern Persian Gulf [3]. This formation is named after the Dalan anticline situated 110 kilometers S-SW of Shiraz. The Dalan formation overlies the Faraghan formation and extends up into the Lower Triassic Kangan formation. The current paper is focused on the facies, sedimentary environment and sequence Stratigraphy study of the Dalan formation in the Assaluyeh gas field the subsurface section of well ASL-A. The Dalan formation in the study site is comprised of relatively clean limestone and dolomite with some intervals rich in oolites and/or peloids with an overall thickness of $830 \mathrm{~m}$. Edgell [4] subdivided the Dalan formation based on lithology into three primary members including: 1) Lower Dalan member, 2) Nar evaporite member and 3) the Upper Dalan member. The Qatar-South Fars Arch is a major regional anticline that runs through the central Persian Gulf and it has a northeast-southwest direction and extends southwards into the Qatar Peninsula.

The geographical coordinates of the studied subsurface section are $52^{\circ} 26^{\prime} 64^{\prime \prime} \mathrm{E}$ and $27^{\circ} 42^{\prime 28.45} \mathrm{~N} \mathrm{~N}$ and overlies West Assaluyeh anticline which is located about $31 \mathrm{~km}$ from Assaluyeh [Figure 1]. This study tends to achieve the following goals:

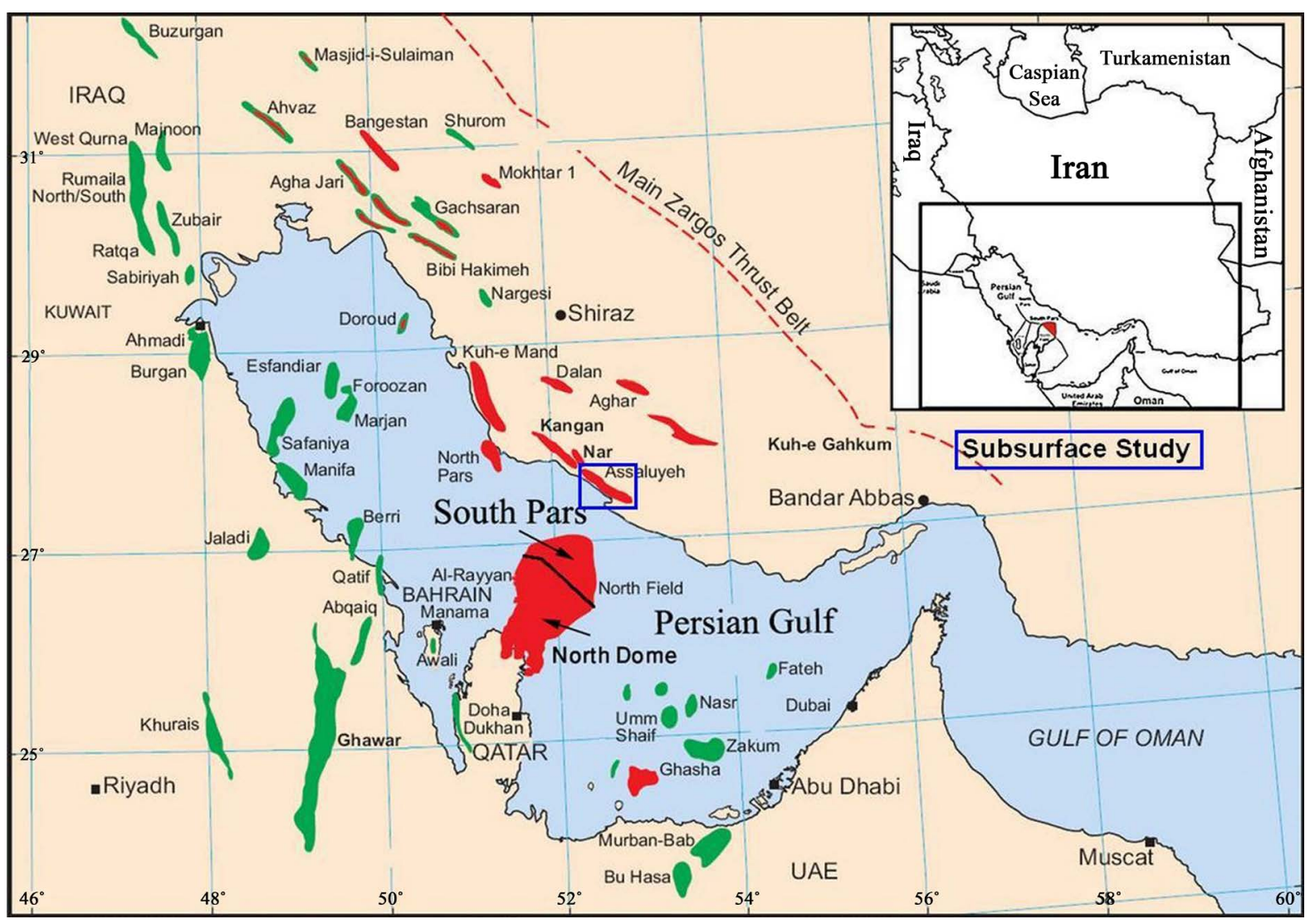

Figure 1. Location map of study area and regions discussed in the text. 
1) Characterize the facies and depositional environments and their stratigraphic distribution.

2) Construct conceptual depositional model for facies distribution of the Assaluyeh gas field.

3) Identify the major depositional sequences and construct a sequence stratigraphic framework based on stacking pattern, type of bounding surfaces which can be used to constrain stratigraphic architecture and reservoir layering.

\section{Methodology}

This research is based on petrographic studies of 830 thin sections obtained from cores and cuttings in the well ASL-A as well as sedimentological interpretation of gamma ray logs for this section. Carbonate rocks were classified according to the schemes of Dunhum, 1962 [5]. Facies analysis and vertical and lateral changes carried out based on [6]-[11]. Sequence Stratigraphy concepts developed by previous workers [2] [12]-[26] were extended to the current study.

\section{Facies Classification}

Facies associations of Dalan formation, covering an area from shore towards the deeper parts of the carbonate ramp, include:

- Facies association A (Tidal flat facies);

- Facies association B (Lagoon facies);

- Facies association C (Shoal facies);

- Facies association D (Open marine facies);

- Facies association E (Mid-ramp facies).

\subsection{Facies Association A (Tidal Flat Facies)}

This facies association is characterized by the following 4 major facies:

\subsubsection{Facies A1 (Massive to Layered Anhydrite)}

Facies description: The anhydrite in this facies can have a variety of forms including massive to finely laminated, sparse fine-grained crystals, nodular, bladed, equivalent to mosaic and needle type. The anhydrite concentrations are generally very high (over $80 \%$ ) and occur in beds from $1 \mathrm{~m}$ to $30 \mathrm{~m}$ thick [Figure 2(a)]. This facies is mostly developed through the Nar Member, but however, has been recognized from Lower and Upper Dalan members.

Depositional environment: This facies developed as supratidal sabkha-type deposits [9] [27]-[29] (associated with nodular, bladed, equivalent to mosaic, needle fabrics and tidal flat sediments) but mainly as shallow coastal Salinas (associated with laminated and massive anhydrite fabrics and hypersaline lagoon deposits). Theses facies may also result from extensive anhydrite replacement of previously deposited carbonates resulting in beds of massive, laminated or nodular anhydrite, but of later origin [1]. They also commonly contain ghosts of the original carbonate textures. Thick layers of anhydrite have been identified in Nar member in Persian Gulf and in the large parts of Arabian platform. The modern analogue for facies A1 can be seen in the western part of Persian Gulf [30] [31].

\subsubsection{Facies A2 (Sandy Dolomudstone)}

Facies description: In this facies quartz grains with wavy extinction are sparse in micritic matrix. Angular grains and absence of overgrowth cement indicate that quartz grains are in their first sedimentary cycle. Dolomitization is one of the most important diagenetic processes of this facies, generating good intercrystalline porosity [Figure 2(b)].

Depositional environment: This facies is found at the base of the Lower Dalan member near the Faraghan sandstones. With respect to the deeping-upward cycles at the base of Lower Dalan member, this facies probably developed on a supratidal environment during transgression of Neo-Tethys [25].

\subsubsection{Facies A3 (Non Burrowed Mudstone)}

Facies description: This facies consists mainly of homogeneous nonfossiliferous mudstone and fine-grain do- 
lomicrite associated with authogenic evaporites. There is no evidence of bioturbation, lagoonal fauna and also fenestral fabric in this facies. Oil stain associated with clay minerals are found in some samples [Figure 2(c)].

Depositional environment: In arid climates due to high salinity and evaporite formation, burrowers and browsers are practically absent in the upper intertidal deposits. Absence of subaerial exposure features indicates deposition in a subtidal lagoon or in an intertidal pond setting. In an arid climate, the pond facies may consist of planar stromatolite and/or evaporitic dolomudstone, depending on geographical location and salinity [11]. This facies is developed in upper intertidal pond setting.

\subsubsection{Facies A4 (Dolomitic Mudstone with Evaporite Casts)}

Facies description: This facies includes fine-crystalline dolomites as well as sparse anhydrite nodules and crystals with needle, fan type and equivalent fabrics. Dolomite crystals are consisting of Dolomicrite (Smaller than $16 \mu \mathrm{m}$ ) to Dolosparite (Greater than $62 \mu \mathrm{m}$ ). Changes between dolomite types, is usually associated with occurrence of pseudo-ooids which is indicative of intertidal environments [Figure 2(d)].

Depositional environment: In upper intertidal environments, anhydrite nodules are generated in the early stage of the diagenesis, syndepositional or post depositional, through direct deposition of sulphate saturated pore waters in capillary zone [9] [32]. Sparse anhydrite crystals, lack of fossils and fine-grained dolomites are evidence for generation of this facies in intertidal, supratidal and other hypersaline environments [6]. In arid climates, evaporitic Dolomudstone can be generated in upper parts of intertidal environments [11].

\subsection{Facies Association B (Lagoon Facies)}

This facies association is characterized by the following 7 major facies:
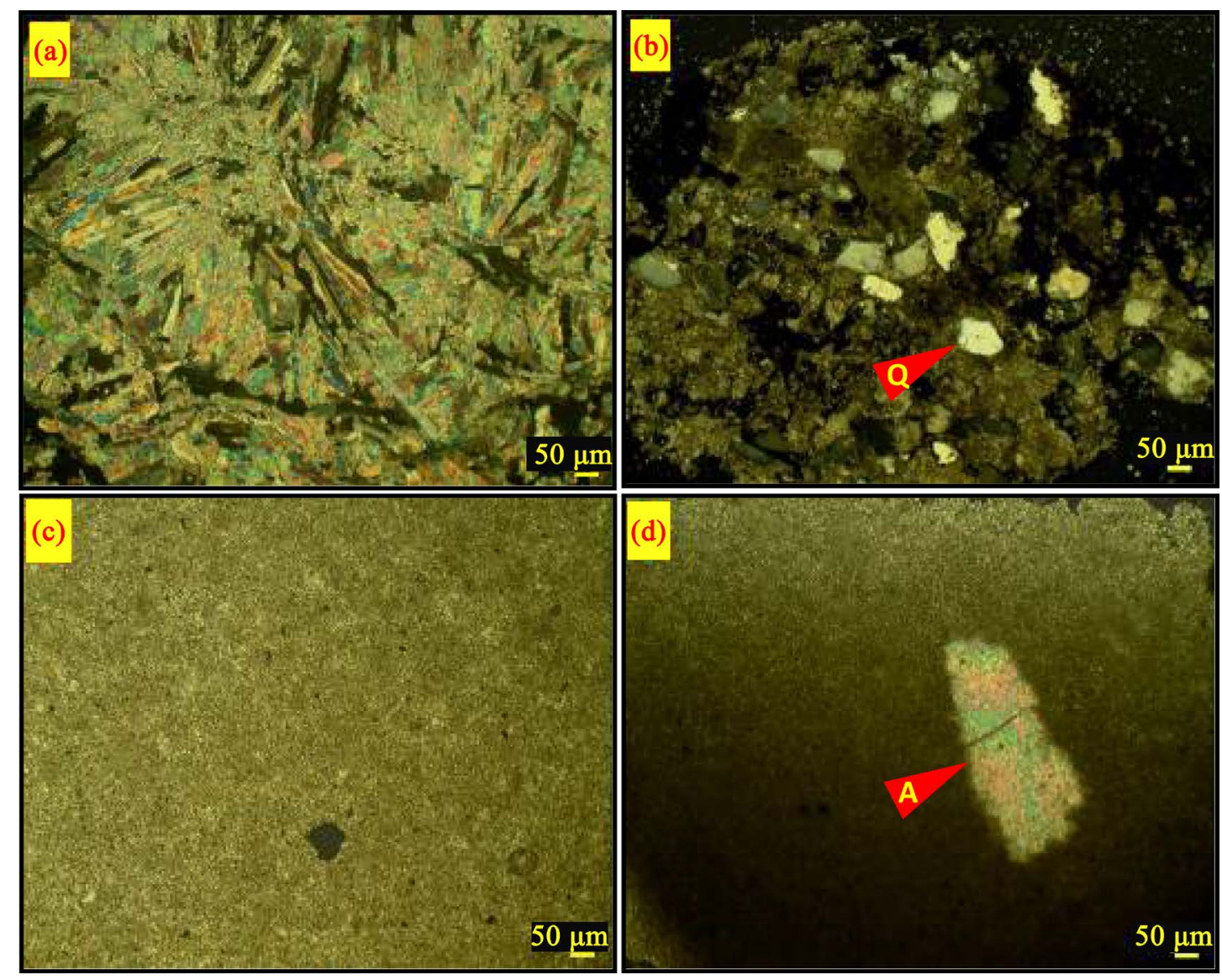

Figure 2. Facies association A (Tidal flat facies): (a) Massive to layered anhydrite with fibrous to needle fabric; (b) Sandy dolomudstone, the quartz grains "Q" are sparse in micritic matrix; (c) Non burrowed mudstone; (d) Dolomitic mudstone with evaporite casts "A" (XPL). 


\subsubsection{Facies B1 (Peloid Packstone)}

Facies description: This facies includes more than $60 \%$ fine-grained peloid with medium sorting and good roundness. This facies is characterized with peloids in different size $(30-200 \mu \mathrm{m})$ which irregularly are sparse. The fossils are rare and only a few benthic foraminifera are seen [Figure 3(a)]. It is not easy to recognize the origin of the peloids, but consideration angular peloids, they are attributed to rounded micritic intraclasts [6] [30]. Dolomitization and void filling anhydrite cement are the most important diagenetic processes.

Depositional environment: Textural and compositional data are used in grouping limestone into genetic categories. Presence and combination of grains are indicative of subfacies types that reflect specific environment conditions and settings on a tidal to subtidal carbonate platform. According to the size and shape of peloids, they are considered as subtype 3 and indicate platform-wide subfacies [33]. Rare skeletal grains and absence of subaerial exposure fabrics are indicative of limited circulation with high salinity. This facies illuminates gradual transition of intertidal settings to lagoonal environments [34]. This facies is developed in protected lagoon environment with moderate water circulation [6].

\subsubsection{Facies B2 (Bioclast Peloid Packstone with Gymnocodiacean)}

Facies description: This facies includes high amount of peloids associated with gymnocodiacean algae in addition of foraminifera (such as Cribrogenerina sp.), gastropods, echinoderms and intraclasts. Dolomitization and cementation are the most important diagenetic processes [Figure 3(b)].

Depositional environment: This facies is characterized by presence of gymnocodiacean algae. Consideration of peloids, they can be attributed to type 3, which belong to low energy lagoonal environments. The amount of gymnocodiacean algae is much more than dasyclads algae in this subsurface section and it can be as a result of paleoecology and biological factors governing the basin conditions [35]. Calcareous green algae point to shallow or very shallow marine water of normal salinity [6].

\subsubsection{Facies B3 (Bioclast Wackestone/Packstone with Algal and Benthic Foraminifera)}

Facies description: This facies consists of calcareous green algae such as dasyclad (Mizzia sp.) and gymnocodiacean (Permocalculus sp.) and benthic foraminifera such as Hemigordius sp., Geinitzina sp. and fusulinids associated with gastropods, ostracods and shell fragments. This facies includes micritic and in some samples cement matrix [Figure 3(c) and Figure 3(d)].

Depositional environment: Dasyclads are the most important calcareous algae used in microfacies analysis. They indicate deposition in shallow or very shallow marine water of normal salinity. Untransported dasyclads point to very shallow depths (tens of centimeters) down to only a few meters. They record photic bottom conditions and occur within the tidal zone and the upper subtidal zone. Mass accumulations of gymnocodiacean in Late Permian and Early Cretaceous Tethyan carbonate platforms are indicative of warm, shallow seas with low to moderate water energy. Mizzia dasyclad is a common feature of Permian proximal platform area [6]. Many larger foraminifera can be taken as good as evidence of shallow photic environments because of their endosymbiotic associations. Assemblage of algae and foraminifera characterize the shallow photic and dysphotic parts of a carbonate ramp [36].

\subsubsection{Facies B4 (Bioclast Wackestone with Echinoderms and Foraminifera)}

Facies description: This facies mostly consists of echinoderms and benthic foraminifera such as Geinitzina sp. and Globivalvulina $s p$. associated with ostracods and intraclasts. This facies includes micritic matrix with syntaxial overgrowth or syntaxial echinoderm cement [Figure 3(e)].

Depositional environment: Echinoderms are found in inner to mid ramp environments [1] but considering benthic foraminifera, adjacency with lagoonal facies and low diversity, this facies developed in lagoonal environments.

\subsubsection{Facies B5 (Fusulinid Wackestone)}

Facies description: This facies consists mainly of fusulinds such as Schwagerina sp. and Verbeekina sp. associated with benthic foraminifera, peloids and intraclasts which are sparse in micritic matrix [Figure 3(f) and Figure 3(g)].

Depositional environment: This facies is in adjacency of mudstone with lagoonal foraminifera facies related to lagoonal environments. Fusulinids are common at the top of Lower Dalan member, but they are also found in 


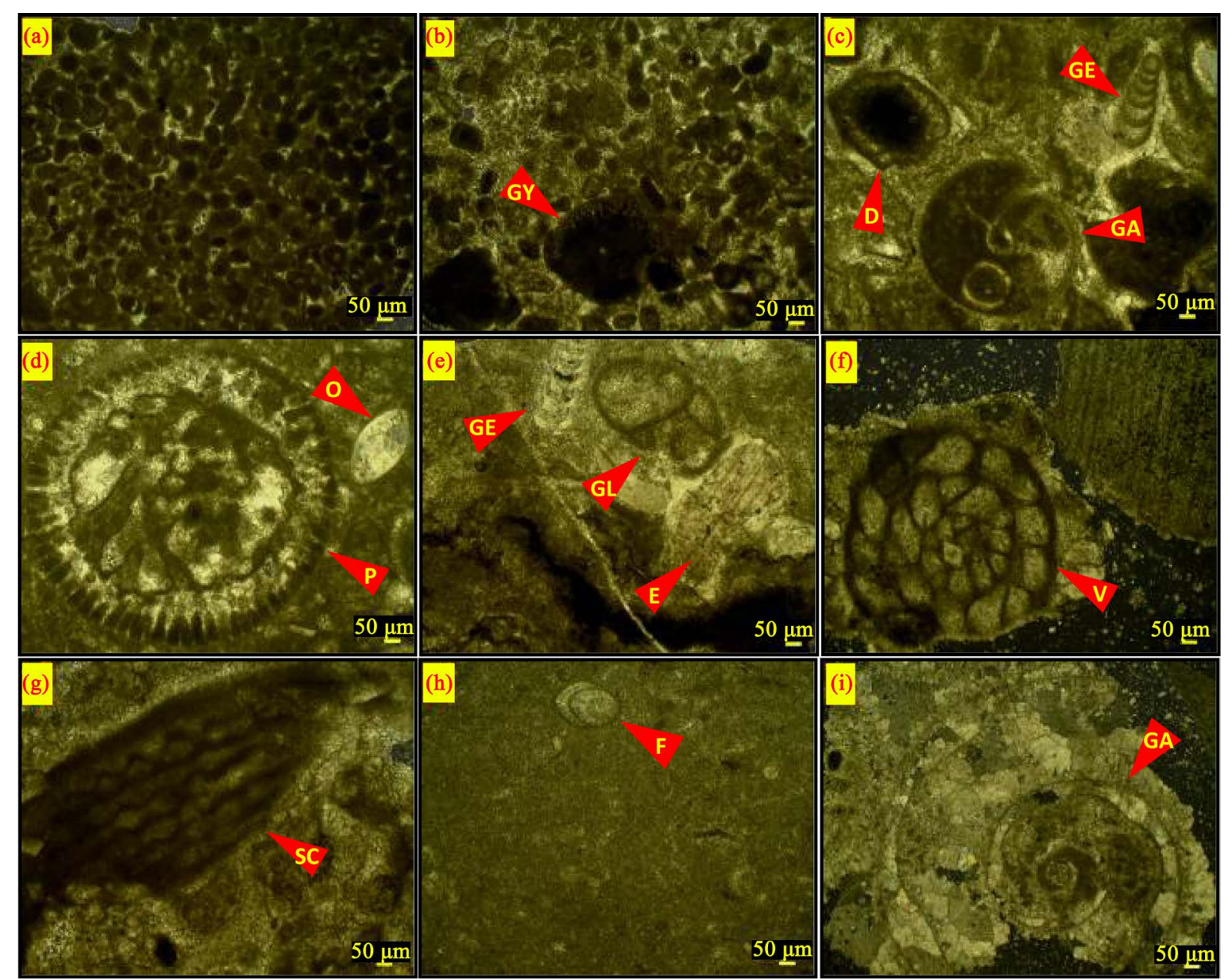

Figure 3. Facies association B (Lagoon facies): (a) Peloid packstone; (b) Bioclast peloid packstone with Gymnocodiacean (GY); (c) and (d) Bioclast wackestone/packstone with algal and benthic foraminifera, Dasyclad (D), Geinitzina sp. (GE), Gastropod (GA), Permocalculus sp. (P) and Ostracod (O); (e) Bioclast wackestone with echinoderms and foraminifera, Geinitzina sp. (GE), Globivalvulina sp. (GL) and Echinoderm (E); (f) and (g) Fusulinid wackestone, Verbeekina sp.(V), Schwagerina sp.(SC); (h) Mudstone with lagoonal foraminifera (F), (i) Bioclast packstone with gastropod (GA) (XPL).

Nar member. Fusulinids are distributed from inner to mid ramp settings, but considering benthic foraminifera, adjacency with lagoonal facies and low diversity, this facies developed in lagoonal environments.

\subsubsection{Facies B6 (Mudstone with Lagoonal Foraminifera)}

Facies description: This facies includes a few amounts of benthic foraminifera. The matrix is micritic and there is no burrowing and bioturbation [Figure 3(i)].

Depositional environment: Combination of textural data such as micritic matrix and compositional data like low diversity as well as present fauna indicates low energy and quiet-water environment [6].

\subsubsection{Facies B7 (Bioclast Packstone with Gastropod)}

Facies description: This facies comprises mostly of gastropods associated with echinoderms, dasyclads, peloids and foraminifera [Figure 3(i)].

Depositional environment: The gastropods are commonly found in all shallow marine environments. They are able to live in brackish and hypersaline waters in which they are abundant but with low diversity. The gastropods are found in inner ramp to mid ramp settings [1], but associated fauna can help us to recognize the living environment of the animals. Echinoderms are found in inner to mid ramp environments and with attention to presence of dasyclads and Foraminifera, this facies is considered as a back-barrier lagoon. 


\subsection{Facies Association C (Shoal Facies)}

This facies association is characterized by the following 5 major facies:

\subsubsection{Facies C1 (Bioclast Intraclast Packstone/Grainstone)}

Facies description: This facies includes 30\% intraclasts which are $100 \mu \mathrm{m}-1.2 \mathrm{~mm}$ associated with foraminifera such as Hemigordius sp. and Geinitzina sp., dasyclads such as Mizzia sp., echinoderms and shell fragments. The matrix consists mostly of marine phreatic cement (Isopachous rimmed cement) and burial cement (mostly mosaic cement). Intraclasts are medium sorted and rounded. Cementation and dolomitization are important diagenetic processes [Figure 4(a)].

Depositional environment: Reworked deposits such as intraclasts and extraclasts are good indicators to determine microfacies types. Therefore, intraclasts can indicate the agitated water or at least transportation. Dasyclads are constituents of Permian non-reefal shallow water limestones [37]. The algae are dominant in backbarrier lagoons and are important producers of sand to clay sized particles. Lack of micrite and high percentage of intraclasts associated with low energy facies are indicative of leeward-shoal settings [38].

\subsubsection{Facies C2 (Bioclast Ooid Grainstone)}

Facies description: Ooid is the most abundant non-skeletal grain, comprising $30 \%-40 \%$ of the allochems. Ooids are mostly normal and micritic. The nuclei of some ooids has been dissolved and filled by dolomite. In addition to ooids, bryozoans and echinoderms can be found. Cementation, compaction, dissolution and dolomitization are common diagenetic processes. Moldic and intergranular porosity are common [Figure 4(b)].

Depositional environment: Aragonite ooids are greatly dissolved and filled by calcite and dolomite or can be seen as moldic porosity, known as Oomoldic porosity. High energy settings are characterized with concentric, micritic and broken ooids. Bryozoans and echinoderms are common in shoals and open marine settings [6], but considering the presence of high energy ooids, this facies is developed in shoal environment.

\subsubsection{Facies C3 (Dolomitized Ooid Grainstone)}

Facies description: This facies contains about $80 \%$ ooids which are $50-500 \mu \mathrm{m}$. The ooids are mimically replaced and they exhibit still traces of their concentric microstructure. Isopachous marine cement is developed around the grains. Dolomitization, dissolution and cementation are the most important diagenetic processes [Figure 4(c)].

Depositional environment: Dissolution and dolomitization have created great quality in this facies and name it as the most important reservoir facies. Composition and presence of grains are indicative of subfacies types, which reflect the environmental condition. Ooids are characterized on the base of shape, size and number of laminae [6]. Furthermore, the maximum and medium size of ooids as well as thickness of their cortex can be used to determine water energy. Ooids are generated in both low and high energy environments. High energy settings are characterized with concentric, micritic and broken ooids, whereas low energy ooids are radial fibrous and asymmetric ooids. This facieses characterized with spherical normal ooids which are smaller than 1 mm including concentric or tangential thin layered cortex that is attributed to shoal settings [33] [39]. Modern examples of tangential aragonitic ooids are Bahamas, Yucatan, Abu Dhabi and Persian Gulf which are considered as very shallow, warm low latitudes seas, common in high energy settings [6].

\subsubsection{Facies C4 (Intraclast Ooid Grainstone)}

Facies description: This facies contains high percentage of ooids which are $200-300 \mu \mathrm{m}$ and also intraclasts of $800 \mu \mathrm{m}$ sized. The ooids are mimically replaced and they exhibit still traces of their concentric microstructure. Isopachous marine cement is developed around the grains. Intraclasts are medium sorted and rounded. Dolomitization, dissolution and cementation are the most important diagenetic processes. Moldic and intergranular porosity are common [Figure $4(\mathrm{~d})$ ].

Depositional environment: This facies is characterized with spherical normal ooids which are smaller than 1 mm including concentric or tangential thin layered cortex that is attributed to shoal settings [33] [39]. High percentage of intraclasts associated with high energy ooids as well as isopachous marine cement is indicative of shoal settings.

\subsubsection{Facies C5 (Coarse-Grain Intraclast Bioclast Grainstone)}

Facies description: This facies contains high percentage of coarse-grain echinoderms, bryozoans and intraclasts 

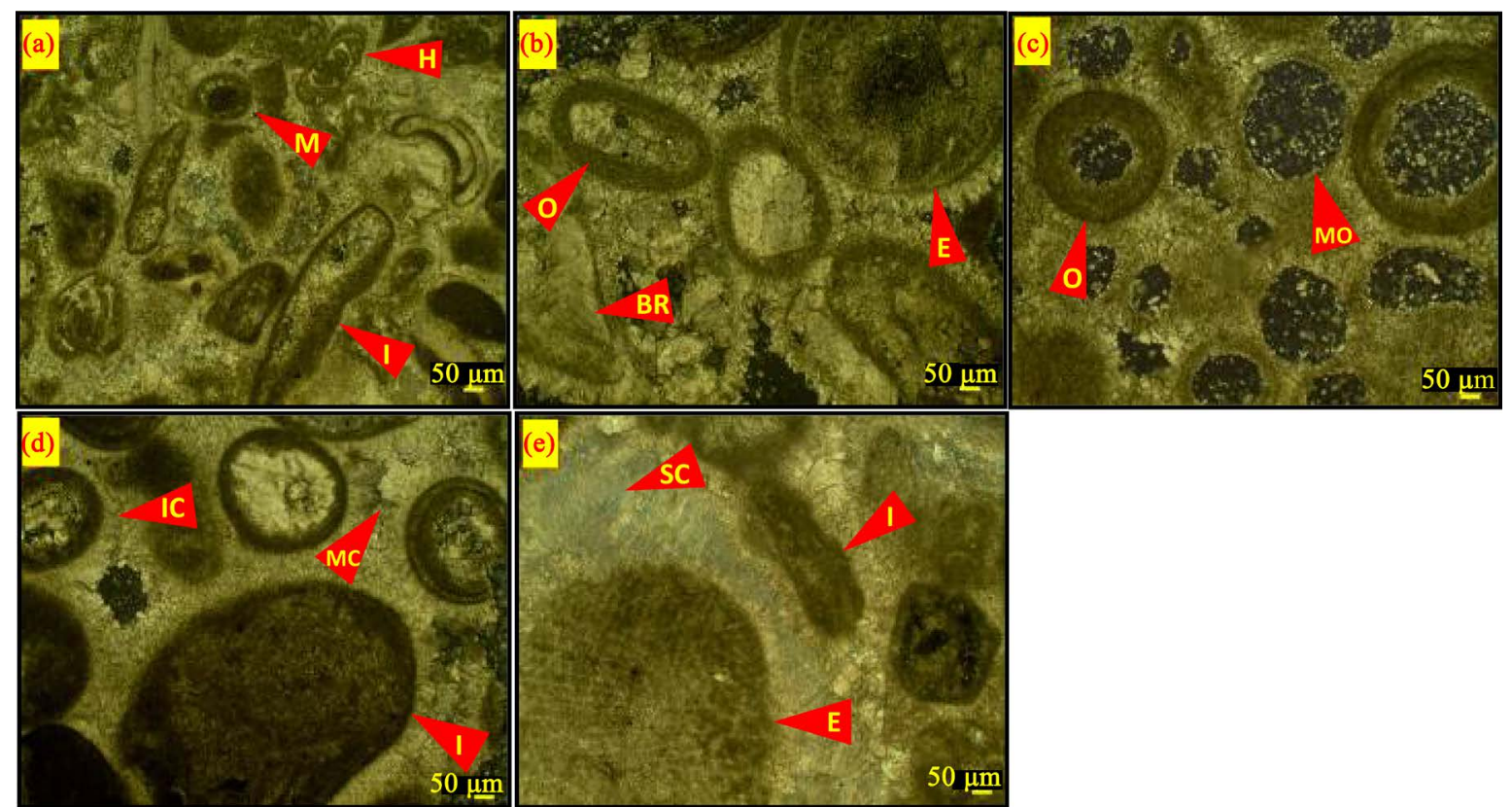

Figure 4. Facies association C (Shoal facies): (a) Bioclast intraclast packstone/grainstone, Hemigordius sp. (H), Mizzia (M) and intraclast (I); (b) Bioclast ooid grainstone, ooid (O), bryozoan (BR) and echinoderm (E); (c) Dolomitized ooid grainstone, tangential ooids (O) and oomoldic porosity (MO); (d) Intraclast ooid grainstone, intraclast (I), mosaic cement (MC) and isopachous rimmed cement (IC); (e) Coarse-grain intraclast bioclast grainstone, echinoderm (E), syntaxial echinoderm cement (SC) and intraclast (I), (XPL).

with few amounts of peloids and ooids reworked from shoal setting. This facies is characterized by coarse grains, lack of micrite and development of marine cement. The cement comprising three types: 1) Isopachous rimmed cement, 2) Burial mosaic cement, and 3) Syntaxial overgrowth or syntaxial echinoderm cement [Figure 4(e)].

Depositional environment: Bryozoans are often the most abundant carbonate grains in non-tropical carbonates. They contribute to characteristic skeletal grain associations (e.g. bryomol association or bryonoderm association). Modern bryozoans are common in cool-water environments ranging from temperate to subpolar settings, but also live in tropical settings and reefs [6]. Paleoenvironmental parameters, such as temperature, salinity, water energy, character of the substrate, and sedimentation rate may be indicated by bryozoans [40].

Paleoenvironmental inferences to be drawn from bryozoan sediments of different ages must be handled with care because Paleozoic and post-Paleozoic bryozoan-rich carbonate deposits have strikingly different global distribution patterns. Paleozoic deposits spread through a wide range of latitudes, but were more common in the tropics except in times of significant cooling (Ordovician, Late Paleozoic). Bryonoderm grain association is characterized by abundant bryozoans associated with echinoderm fragments. Most echinoderms are cystoid plates. Assessing the water depth of a carbonate ramp, bryozoan and echinoderm association is indicative of Zone 2 (Euphotic) which frequently reworks echinoderms [41].

\subsection{Facies Association D (Open Marine Facies)}

This facies association is characterized by the following 2 major facies:

\subsubsection{Facies D1 (Bioclast Wackestone/Packstone with Abundant Echinoderms)}

Facies description: This facies consists mostly of echinoderms associated with bryozoans and ostracods. The matrix includes micrite and spary cement. The oil stain is seen in some samples. Most of grains are broken but, however, some whole skeleton bryozoans are found. Facies D1 is common in Lower Dalan Member and is adjacent with Shoal facies [Figure 5(a) and Figure 5(b)].

Depositional environment: Bryozoans are often the most abundant carbonate grains in non-tropical carbonates. Assessing the water depth of a carbonate ramp, bryozoan and echinoderm association is indicative of Zone 2 (Euphotic) which frequently reworks echinoderms [41]. Considering lack of green algae and rare intrac- 


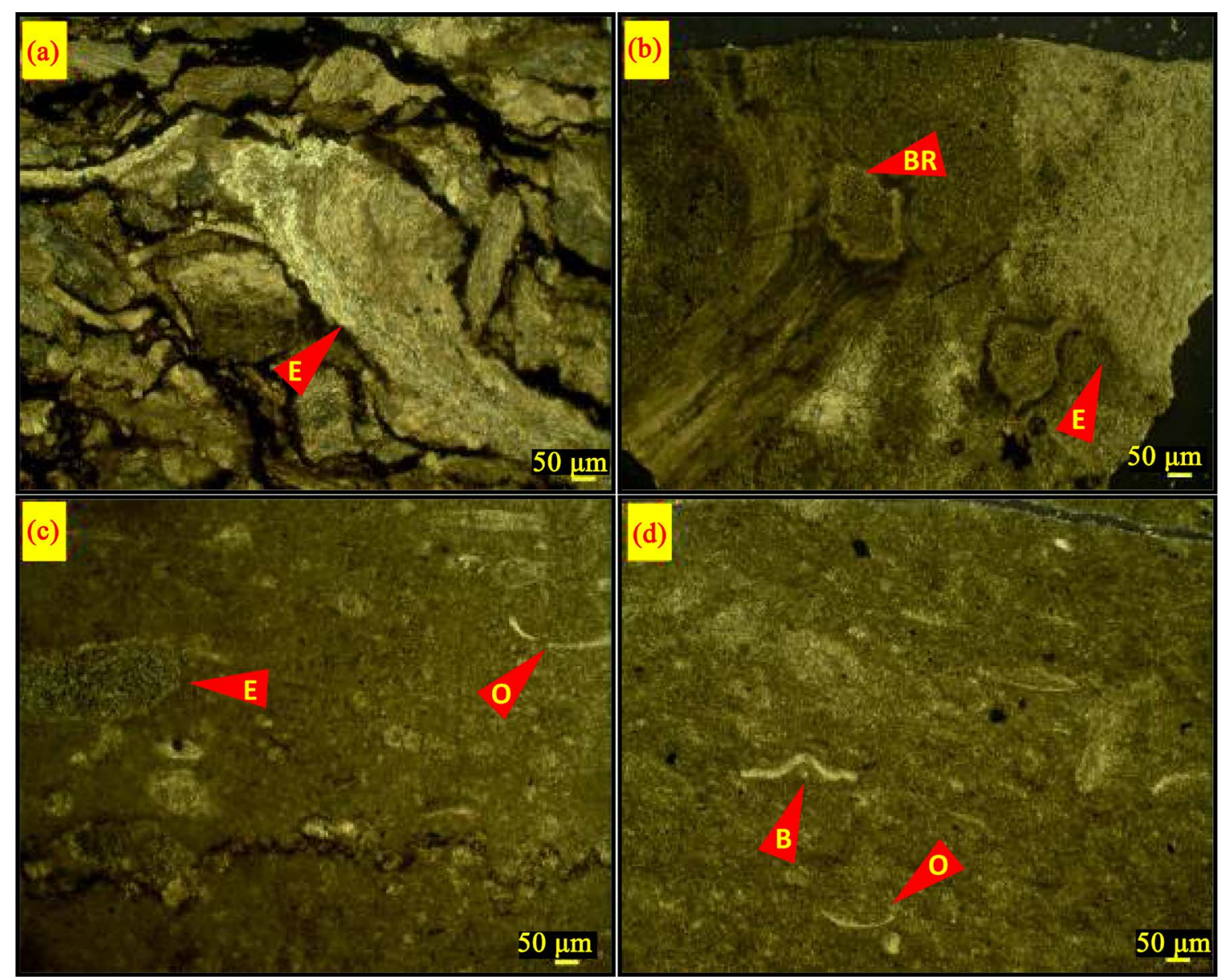

Figure 5. Facies association D (Open marine facies): (a) (b) Bioclast wackestone/packstone with abundant Echinoderms, echinoderms (E) and bryozoans (BR); (c) and (d) Bioclast mudstone, echinoderms (E), brachiopods (B) and ostracods (O) are sparse in micritic matrix (XPL).

lasts and also presence of whole bryozoans and echinoderms, this facies is developed in open-marine environments with low energy levels.

\subsubsection{Facies D2 (Bioclast Mudstone)}

Facies description: This facies contains low percentage of echinoderms, ostracods and brachiopods which are spars in micritic matrix [Figure 5(c) and Figure 5(d)].

Depositional environment: Rare skeletal grains, Lack of evaporites as well as intraclasts and abundant micrite are indicative of offshore low energy environments [42]. This facies is developed in open-marine settings near the mid ramp.

\subsection{Facies Association E (Mid-Ramp Facies)}

This facies association is characterized by the following facies:

Facies E1 (Argillaceous Mudstone/Shale)

Facies description: There is no carbonate allochems in this facies. The micritic matrix has got dark brown color due to presence of clay minerals which are classified as non-carbonate components [Figure 6]. The presence of clay material is approved by petrographical characteristic such as dull and brown appearance with thin lamination as well as petrophysical characteristic obtained by sonic and gamma-ray logs. A sudden increase in gammaray response is seen against the clay mineral bearing facies [12].

Depositional environment: The clay minerals are found in various environments especially in marine set- 


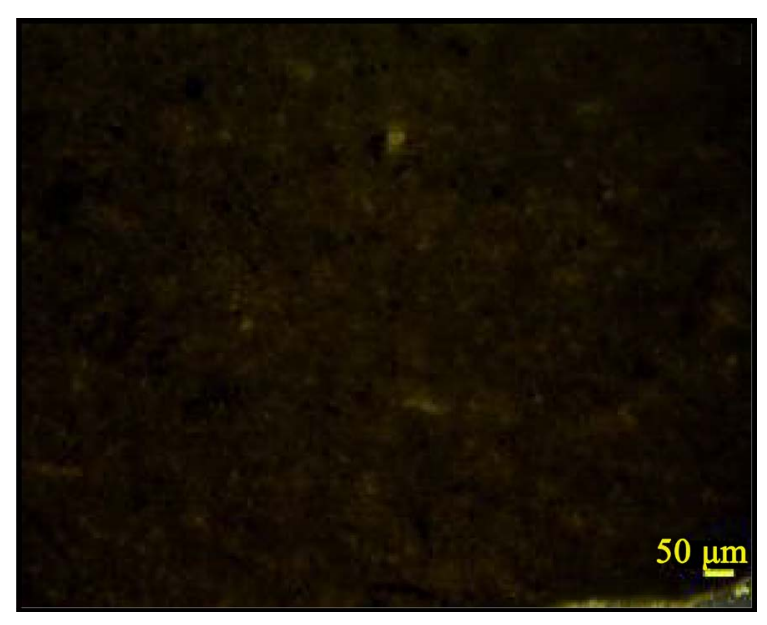

Figure 6. Facies association E: Argillaceous mudstone/shale.

tings. Considering the position of this facies in stratigraphical succession, it has been generated in mid-ramp environments. Rapid increase in water depth is usually associated with transgration and sediment starvation in deeper-water environments which cause distribution of thin layered sediments with parallel nature known as "Condensed section". The main elements to recognize condensed section include abundance of clay minerals, pelagic deposits, diagenetic features such as aragonite, glauconite and phosphate cements as well as bioturbation. The condensed section is characterized by sudden increase in gamma-ray response [12] [13] [43].

\section{Depositional Model of Dalan Formation}

Integrating the facies, sedimentological interpretations, classification of the facies association and also evaluation of their lateral and vertical patterns based on standard facies belts and framework developed for the study, conceptual depositional model has been constructed for Dalan formation in Assaluyeh gas field, well ASL-A subsurface section [Figure 7]. The general palaeogeographic context of this system was a marginal marine shelf setting with an inner platform that was very flat, ramp-like, with little topography [44], but with local depresssions. Gradual changes between relatively widespread facies belts, lack of breccias and turbidites, presence of high energy grainstones in shoreline environments associated with calcareous green algae and benthic foraminifera are indicative of homoclinal ramp setting. The dominant grain type of carbonate ramps are skeletal grains and ooids, followed by peloids and intraclasts [6]. Other grain types are quantitatively of minor importance (Cortoids, Oncoids), or are very rare or totally absent (Pisoids and aggregates). Abundant aggregate grains are characteristic of carbonate platforms, but missing in ramps [Figure 8]. The ramp becomes more distal to the northeast with the presence of more open-marine influences (D1 and D2 facies). In the inner shelf areas, where most of reservoir facies sedimentation took place, depositional environments were prone to be restricted with limited circulation due to high carbonate production low accommodation potential. It was necessary to create accommodation for extensive shoal development and hence reservoir development. The essential development of accommodation was initiated platform flooding and hence transgression. Inversely, sea-level falls can quickly and drastically isolate the platform interiors reducing the internal hydrodynamic energy levels thus stopping the development of reservoirs over vast areas, and creating widespread evaporitic and carbonate mud seals. There are no modern analogues for such epeiric seas in term of platform morphologies and scales, nor extent of facies distribution and their sediment dynamics.

The palaeolatitudes for the Khuff platform were about $20^{\circ} \mathrm{S}-25^{\circ} \mathrm{S}$ for the Late Permian [45] [46]. This places the platform in an arid and semi-tropical climate belt. This is consistent with the sedimentological and stratigraphic evidence from the study area which suggest more depositional evaporites and hypersaline lagoons in the Permian. Moreover, during the Permian, the Khuff platform experienced rising temperatures due to global warming, following the Carboniferous-Early Permian glaciations/and the north ward latitudinal drift towards lower tropic latitudes [46]. The Dalan formation is developed on the margin of the Neo-Tethys, an ocean separating Gondwana supercontinent and the Gondwana Terranes (Cimmerian megablock). The Dalan formation is thus interpreted as reflecting a major tectono-eustatic event related to the onset of rapid thermal subsidence of 


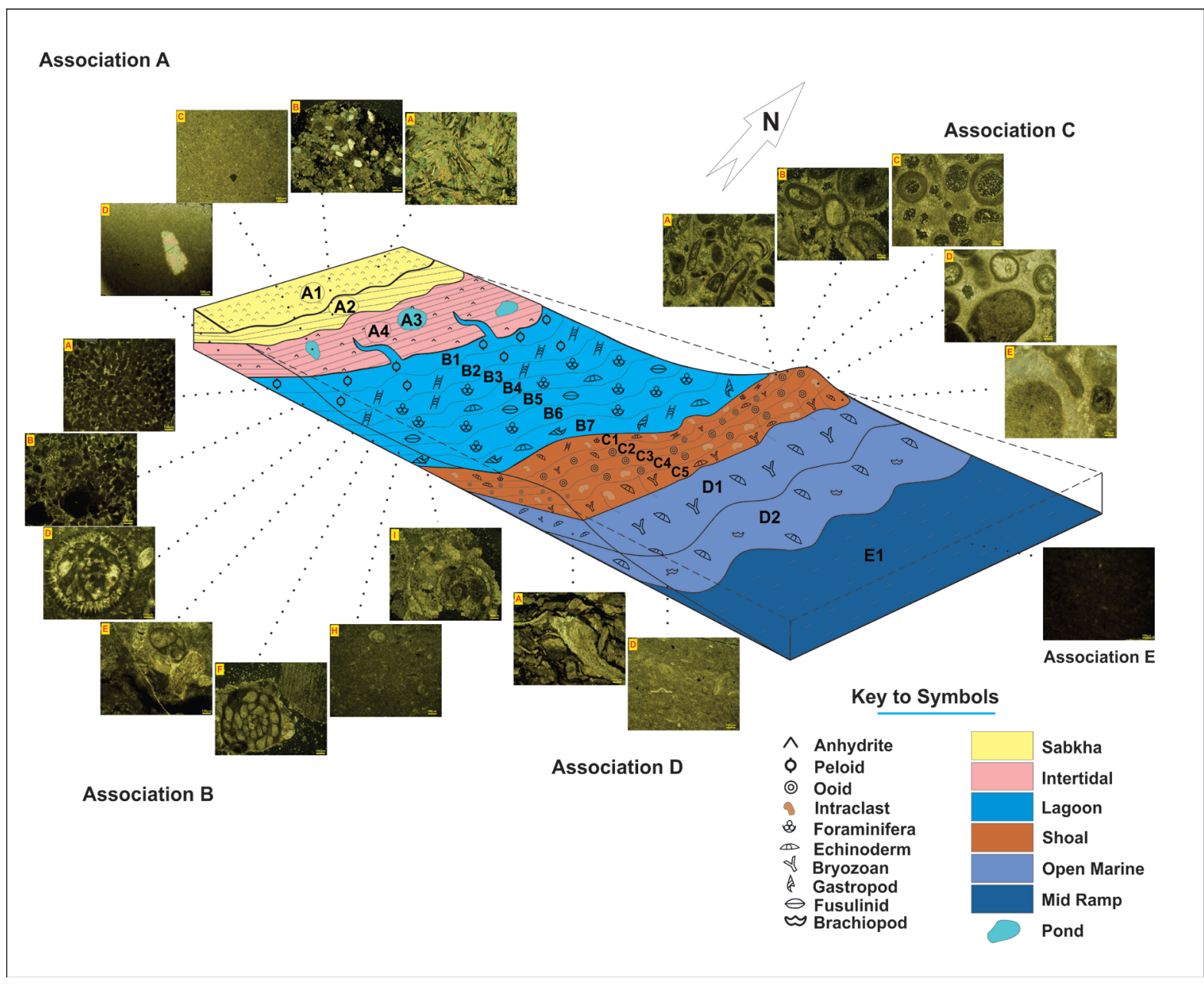

Figure 7. Conceptual depositional model of Dalan formation in Assaluyeh gas field (Well ASL-A, subsurface section).

the early Neo-Tethys passive margin in Arabia and Iran, and the drowning of its rift shoulders. By the Late Permian, sea-floor spreading, thermal subsidence and the associated transgression let to the development of a very large epeiric platform shelf which stretched from Iran to Saudi Arabia [1].

\section{Sequence Stratigraphy of Dalan Formation}

Stratigraphically, this study is focused on the Middle to Late Permian Dalan formation in the Assaluyeh gas field. This stratigraphic unit is subdivided into three reservoir intervals with K5 being Lower Dalan and K4 and K3 being Upper Dalan [47]. The Dalan and Kangan formations form a large second-order cycle with a major transgression within the Lower Dalan, a high stand located around the Upper Dalan and a sequence boundary at the top of Kangan [1] [23] [48] (AP6, $270.6 \mathrm{Ma}$ ). The sequence stratigraphic interpretation is based on the stacking pattern and depositional environments. The large third-order stacking cycles, defined on the basis of cycles bounded by surfaces representing base-level and accommodation potential minima have been identified and regionally correlated based on stratigraphic stacking pattern, faunal and floral events. These large-scale cycles provide the framework to the description and interpretation of the study area. The cycles defined are as follows:

Cycle 1 (LDS-1): The first deposition sequence includes Lower Dalan member and encompassing the main part of K5 reservoir. Its lower boundary with Faraghan sandstone is Subaerial Unconformity (SU) and a succession of lagoonal (B2, B3 and B7), Shoal (C1- C3) and open-marine (D) facies in retrogradation stacking pattern is indicative of transgressive system tract (TST) of this sequence. The maximum flooding surface (MFS) of this unit is marked by mid-ramp argillaceous and shaly deposits (E1) comprising "condensed zone” (Picked by sud- 

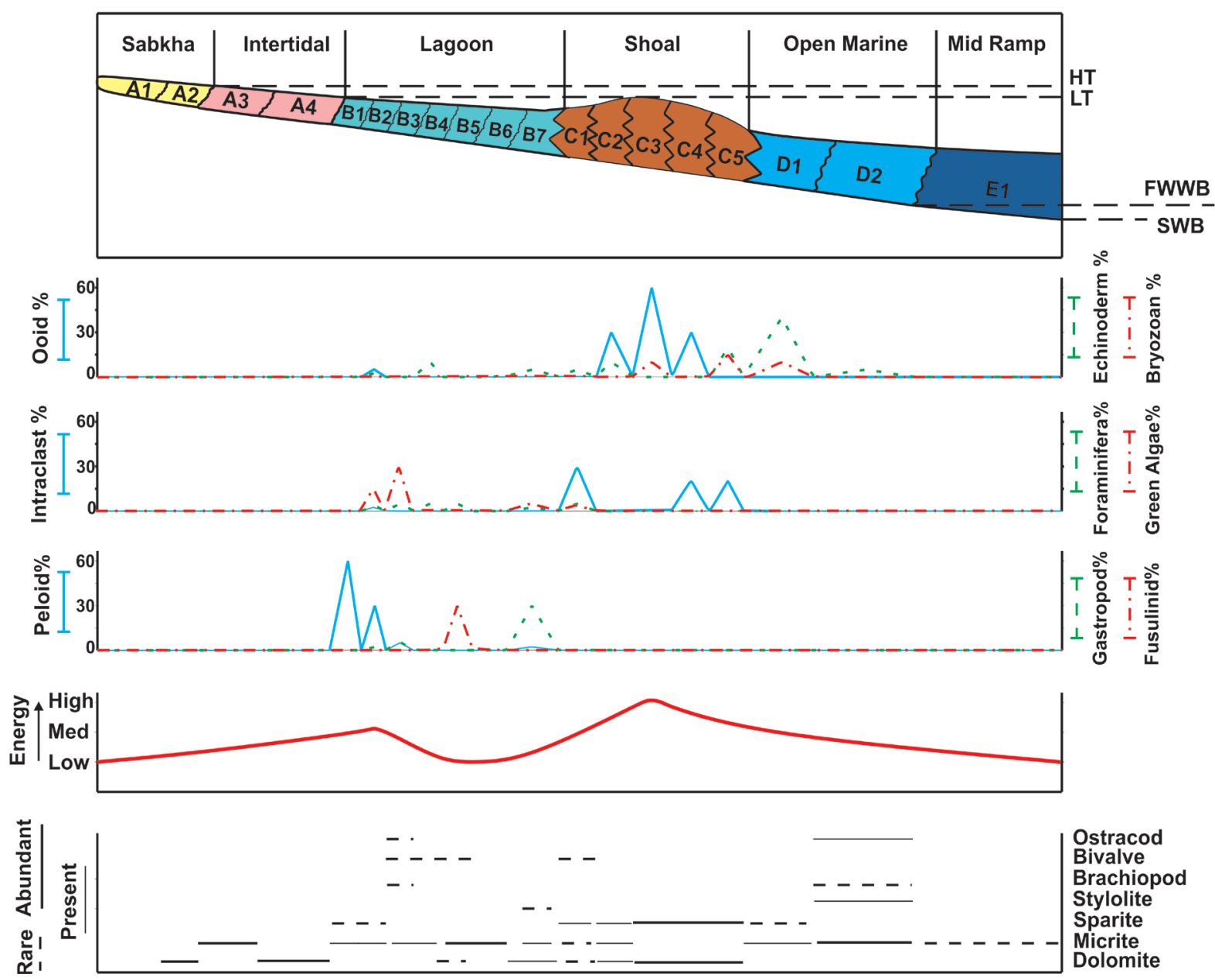

Figure 8. Depositional model of the Dalan formation. The dominant grain types are ooids, peloids and intraclasts followed by skeletal grains which are indicative of carbonate ramps.

den increase in gamma-ray response). Highstand system tract (HST) depositional sequence is recognized by open-marine sequences (D1 and D2), Shoal (C1) to protected lagoonal facies (B1, B2 and B4) and intertidal facies (A4) that is capped by supratidal (sabkha) evaporitic facies (A1). The upper boundary of this cycle is Correlative Conformity (CC). The lower boundary of this cycle would correspond to the Global Stratotype Section and Point (GSSP, CC $268 \mathrm{Ma}$ ) of Simmons et al., 2007 [24] and sea-level falling of Gradstein et al., 2004 [22] as well as Snedden \& Liu, 2010 [15]. The maximum flooding surface of this cycle would correspond to the P20 MFS of Sharland et al., 2001 and 2004 [23] [24], Wor 1 of Snedden \& Liu, 2010 [15] and sea-level rising of Gradstein et al., 2004 [22]. The upper boundary of this cycle would correspond to the GSSP (CC 265.8) [24] and sea-level falling of Gradstein et al., 2004 [22] as well as Snedden \& Liu, 2010 [15] [Figure 9].

Cycle 2 (LDS-2): This sequence includes Middle Lower Dalan member and encompassing the middle part of K5 reservoir. Its lower boundary with Cycle 1 is Correlative Conformity (CC) and a succession of intertidal (A4), protected lagoonal facies (B1 and B3), shoal (C5) to open marine facies (D2) in retrogradation stacking pattern is indicative of transgressive system tract (TST) of this sequence. The maximum flooding surface (MFS) of this unit is marked by open marine bioclast mudstone (D2). Highstand system tract (HST) depositional sequence is recognized by shoal facies (C2-C4), lagoonal facies (B1, B2 and B4) and intertidal facies (A4) that is capped by intertidal facies (A4). The upper boundary of this cycle is Correlative Conformity. The maximum flooding surface of this cycle would correspond to the Wor 3 of Snedden \& Liu, 2010 [15]. The upper boundary of this cycle would correspond to sea-level falling of Snedden \& Liu, 2010 [15] and sea-level falling of Gradstein et al., 2004 [22] [Figure 9].

Cycle 3 (LDS-3): This sequence includes Upper Lower Dalan member and encompassing the upper part of 


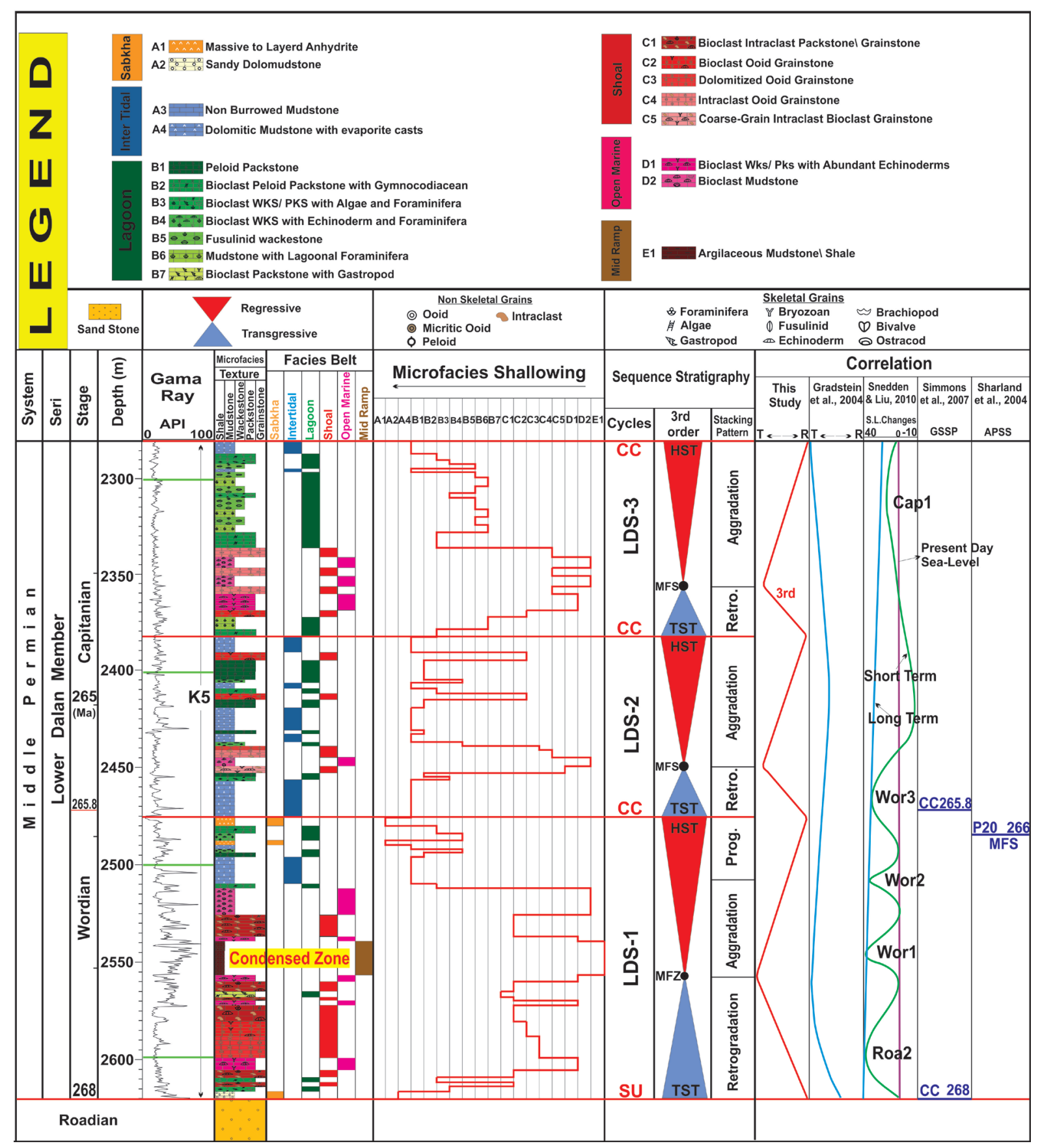

Figure 9. Lower Dalan transgressive-regressive cycles and their correlations with last calibrated sea-level changes and Global Stratotype Section and Points (GSSP).

K5 reservoir. Its lower boundary with Cycle 2 is Correlative Conformity (CC) and a succession of protected lagoonal facies (B2 and B6), shoal (C2 and C4) to open marine facies (D1 and D2) in retrogradation stacking pattern is indicative of transgressive system tract (TST) of this sequence. The maximum flooding surface (MFS) of this unit is marked by open marine bioclast mudstone (D2). Highstand system tract (HST) depositional sequence, which passes through the Nar member, is recognized by Shoal facies (C4), Lagoonal facies (B2, B3, B5 and B6) and intertidal dolomudstone with evaporite cast (A4) that is capped by supratidal evaporitic facies (A1). The upper boundary of this cycle is Correlative Conformity. The maximum flooding surface of this cycle would correspond to the Cap1 of Snedden \& Liu, 2010 [15] and sea-level rising of Gradstein et al., 2004 [22]. The upper 
boundary of this cycle would correspond to sea-level falling of Snedden \& Liu, 2010 [15] [Figure 9].

Cycle 4 (Nar-S): This sequence includes Nar member [Figure 10]. Its lower boundary with Cycle 3 is Correlative Conformity (CC) and a succession of intertidal (A4) and lagoonal (B2 and B3) facies in retrogradation stacking pattern is indicative of transgressive system tract (TST) of this sequence. The maximum flooding surface (MFS) of this unit is marked by protected lagoonal facies (B3). Highstand system tract (HST) depositional sequence is recognized by lagoonal (B1, B2 and B3) and intertidal (A4) and evaporitic (A1) facies in aggradation stacking pattern that is capped by supratidal (sabkha) evaporitic facies (A1). The upper boundary of this cycle considering thick anhydrite layers is Subaerial Unconformity (SU). The maximum flooding surface of this cycle would correspond to the Cap 3 of Snedden \& Liu, 2010 [15]. The upper boundary of this cycle would correspond sea-level falling of Gradstein et al., 2004 [22], Snedden \& Liu, 2010 [15] and GSSP (CC 260.4 Ma) of Simmons et al., 2007 [24]. This cycle is characterized by global warming and sea-level falling evidenced by intertidal to supratidal evaporitic facies.

Cycle 5 (UDS-1): This sequence includes Lower Upper Dalan member comprising K4 reservoir [Figure 11]. Its lower boundary with NAR-S Cycle is Subaerial Unconformity (SU) and a succession of intertidal (A4), Lagoonal (B1, B2, B4 and B7), shoal (C1) and open marine (D1) facies in aggradation-retrogradation stacking pattern is indicative of transgressive system tract (TST) of this sequence. The maximum flooding surface (MFS) of this unit is marked by mid-ramp (E1) facies. Highstand system tract (HST) depositional sequence is recog-

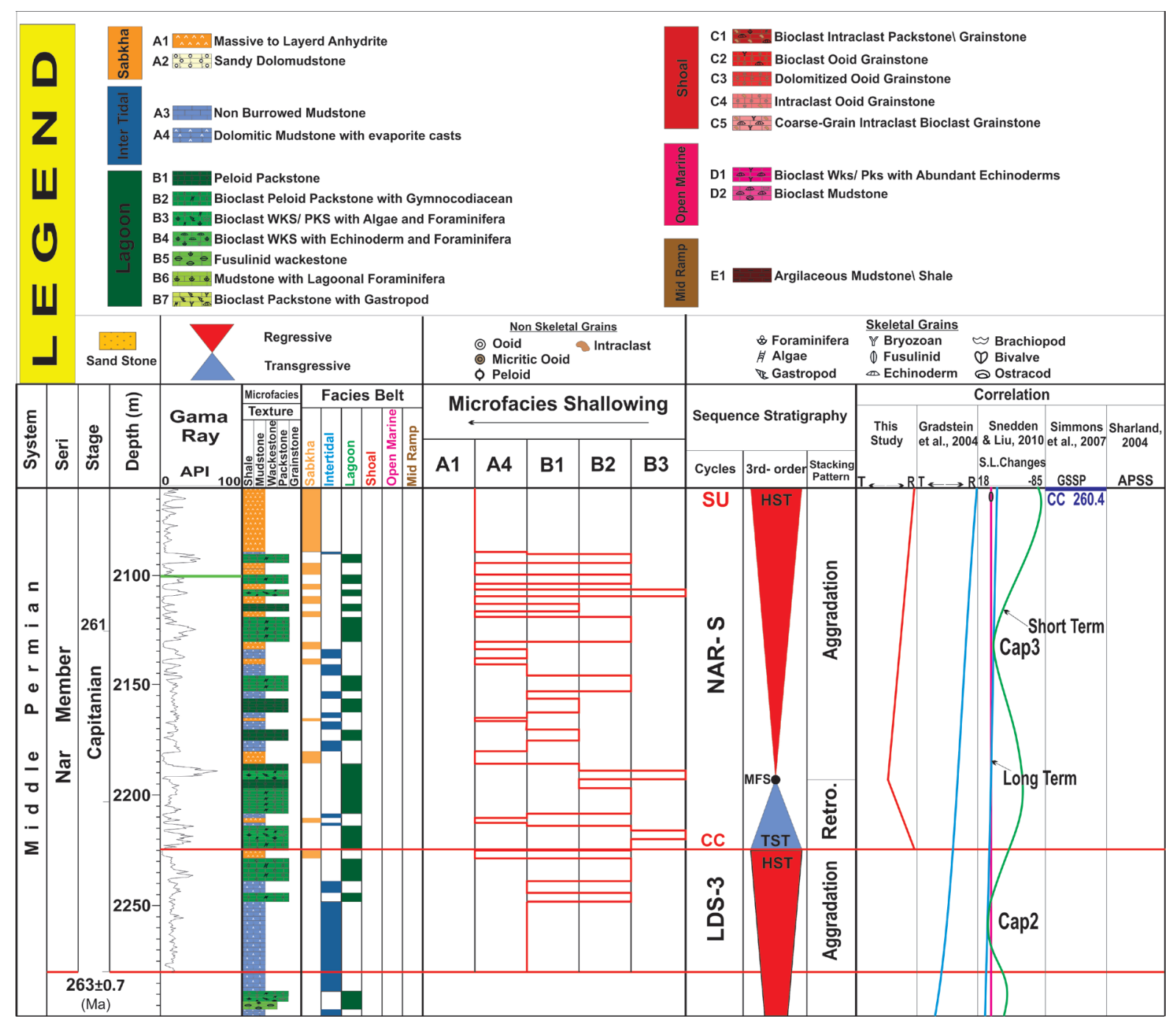

Figure 10. Nar member transgressive-regressive cycles and their correlations with last calibrated sea-level changes and Global Stratotype Section and Points (GSSP). 


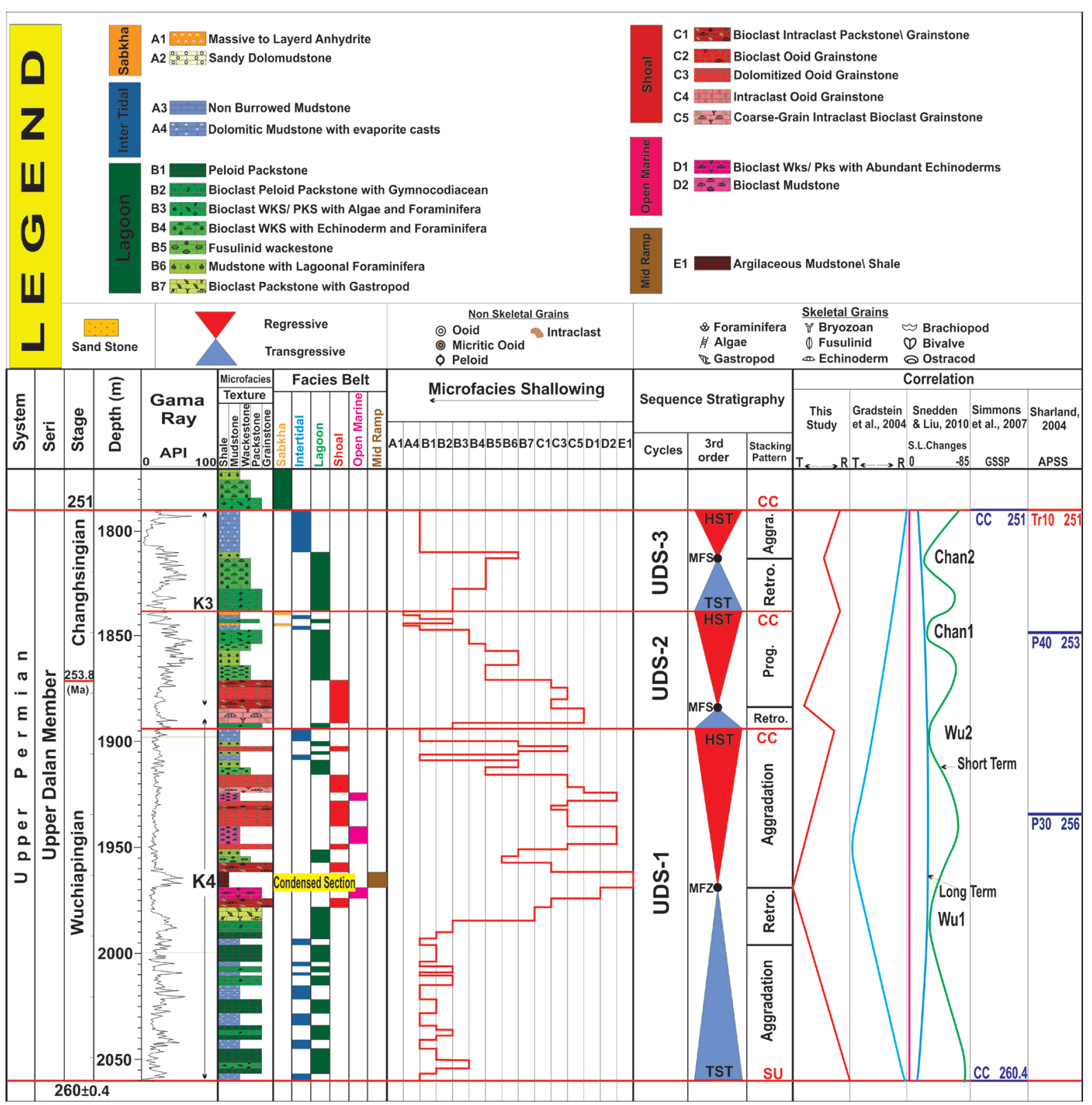

Figure 11. Upper Dalan member transgressive-regressive cycles and their correlations with last calibrated sea-level changes and Global Stratotype Section and Points (GSSP).

nized by open-marine (D2), Shoal (C, C3 and C5), lagoonal facies (B4-B6) in aggradation stacking pattern that is capped by intertidal (A4) facies. The upper boundary of this cycle is Correlative Conformity (CC) because there is no evidence of subaerial exposure. Upper Dalan member is characterized by Late Permian global glaciations and melting events resulting local sea-level changes evidenced by abundant $4^{\text {th }}$-order cycles comprising Upper Dalan $3^{\text {rd }}$-order depositional cycles. The maximum flooding surface of this cycle would correspond to the P30 MFS of Sharland et al., 2001 and 2004 [23] [44], Wu1 of Snedden \& Liu, 2010 [15] and MFS of Gradstein et al., 2004 [22].

Cycle 6 (UDS-2): This sequence includes Middle Upper Dalan member comprising lower part of K3 reservoir [Figure 11]. Its lower boundary with cycle 5 is Correlative Conformity (CC) and a succession of lagoonal (B2) and Shoal (C5) facies in retrogradation stacking pattern is indicative of transgressive system tract (TST) of this sequence. The maximum flooding surface (MFS) of this unit is marked by thick coarse grain intraclast bioclast grainstone (C5) that have been developed due to thermal subsidence and sea-level rising resulted by glac- 
iations events [1] [46]. Highstand system tract (HST) depositional sequence is recognized by shoal (C1, C3), lagoonal (B2-B4 and B6) and intertidal (A4) facies in progradation stacking pattern that is capped by supratidal evaporitic (A1) facies. The upper boundary of this cycle is Correlative Conformity (CC) because there is no evidence of subaerial exposure. The maximum flooding surface of this cycle would correspond to the Wu2 of Snedden \& Liu, 2010 [15].

Cycle 7 (UDS-3): This sequence comprising upper part of K3 reservoir [Figure 11]. Its lower boundary with cycle 6 is Correlative Conformity (CC) and a succession of lagoonal (B2 and B4) facies in retrogradation stacking pattern is indicative of transgressive system tract (TST) of this sequence. The maximum flooding surface (MFS) of this unit is marked by mudstone with lagoonal foraminifera (B6). Highstand system tract (HST) depositional sequence is recognized by intertidal (A4) facies in aggradation stacking pattern. The upper boundary of this cycle is Correlative Conformity (CC) because there is no evidence of subaerial exposure. The maximum flooding surface of this cycle would correspond to P40 MFS of Sharland et al., 2001 and 2004 [23] [44], Chan 2 of Snedden \& Liu, 2010 [15]. The upper boundary of this cycle would correspond to Tr10 (251 Ma) of Sharland et al., 2001 and 2004 [23] [44], CC 251 (GSSP) of Simmons et al., 2007 [24] and sea-level falling of Gradstein et al., 2004 [22] representing the end-Permian mass extinction.

\section{Conclusions}

1) Based on microfacies analysis and significant founa and flora, nineteen major facies in five facies associations including Tidal flat (A), Lagoon (B), Shoal (C), Open-marine (D) and Mid-ramp (E) were recognized in the Dalan formation.

2) Facies A1 to A4 are indicative of Tidal flat environments with high evaporation. These facies are well developed in Nar member due to sea-level fall and global warming.

3) Restricted lagoonal facies are found in most part of Dalan formation especially in Nar and Upper Dalan members. Lower Upper Dalan and Nar members are mostly peloidal ramps but upper part of Upper Dalan which comprising K3 reservoir is mostly bioclastic ramp.

4) The Shoal facies is the most important unit in the Dalan formation. This facies is well developed in Lower and Upper Dalan members comprising K5 and K4 reservoirs. Shoal C3 and C4 facies with well developed intergranular and Oomoldic porosity associated with mimic dolomitization are the most important reservoir facies.

5) The Open-marine facies (D1 and D2) are found both in Lower and Upper Dalan but well developed in Lower Dalan member.

6) The Mid-ramp E1 facies is found both in Lower and Upper Dalan members comprising condensed sections of LDS-1 and UDS-1.

7) The general palaeogeographic context of Dalan formation was a marginal marine shelf setting with an inner platform that was very flat, ramp-like, with little topography, but with local depressions. Gradual changes between relatively widespread facies belts, lack of breccias and turbidites, presence of medium energy packstone/grainstone facies in shoreline environments associated with calcareous green algae and benthic foraminifera are indicative of homoclinal ramp setting. The dominant grain type of carbonate ramps are skeletal grains and ooids, followed by peloids and intraclasts. Other grain types are quantitatively of minor importance (Cortoids, Oncoids), or are very rare or totally absent (Pisoids and aggregates). Abundant aggregate grains are characteristic of carbonate platforms, but missing in ramps.

8) The Dalan formation is interpreted as reflecting a major tectono-eustatic event related to the onset of rapid thermal subsidence of the early Neo-Tethys passive margin in Arabia and Iran.

9) Open-marine facies are developed in Transgressive System Tract (TST) especially at Lower Dalan member which are influenced by major transgression of the Absaroka second-order cycle within the Lower Dalan member.

10)The shoal facies are common in early HST especially in Upper Dalan member which is influenced by the Absaroka HST around the upper Dalan. The accommodation for thick layer oolitic grainstone was generated by transgression and thermal subsidence in Upper Dalan formation.

11)Dolomitization and high evaporation are common in the Late HST due to global sea-level falling.

12)High frequency cycles in the Upper Dalan member are a result of galciation and melting events in the Late Permian. 


\section{Acknowledgements}

The authors would like to thank NIOC Exploration for permission to publish this study. The authors would also like to express thanks to the people whom had valuable contribution to various aspects of this study.

\section{References}

[1] Insalaco, E., Virgone, A., Courme, B., Gaillot, J., Kamali, M., Moallemi, A., Lotfpour, M. and Monibi, S. (2006) Upper Dalan Member and Kangan Formation between the Zagros Mountains and Offshore Fars, Iran: Depositional System, Biostratigraphy and Stratigraphic Architecture. GeoArabia, 11, 74-176.

[2] Fotovat, M., Hosseini, G.H. and Rahimpour-Bonab, H. (2012) Sedimentary Environment of Upper Dalan Member in Qatar-Fars Arch and Its Eastern Margin: South Pars and Salman fields (In Persian). Stratigraphy and Sedimentology Researches, 42, 115-136.

[3] Ghazban, F. (2007) Petroleum Geology of the Persian Gulf. Tehran University and National Iranian Oil Company, Tehran.

[4] Edgell, H.S. (1977) The Permian System as an Oil and Gas Reservoir in Iran, Iraq and Arabia. Proceedings of the Second Iranian Geological Symposium, 161-201.

[5] Dunham, R.J. (1962) Classification of Carbonate Rocks According to Depositional Texture. In: Ham, W.E., Ed., Classification of Carbonate Rocks, a Symposium, AAPG Mem., No. 1, 108-121.

[6] Flügel, E. (2010) Microfacies of Carbonate Rocks, Analysis, Interpretation and Application. Springer-Verlag, Berlin, $996 \mathrm{p}$.

[7] Carozzi, A.V. (1989) Carbonate Rocks Depositional Model. Prentice Hall, Upper Saddle River, 604 p.

[8] Davis, R.A. and Dalrymple, R.W. (2012) Principle of Tidal Sedimentology. Springer, New York, 638 p.

[9] Warren, J.K. (2006) Evaporites: Sediments, Resources and Hydrocarbons. Springer Verlag, New York, 1041 p. http://dx.doi.org/10.1007/3-540-32344-9

[10] Lasemi, Y. (2001) Facies Analysis, Depositional Environments and Sequence Stratigraphy of the Upper Pre-Cambrian and Paleozoic Rocks of Iran (in Persian). Geological Survey of Iran, Tehran, 180 p.

[11] Lasemi, Y., Jahani, D., Amin-Rasouli, H. and Lasemi, Z. (2012) Ancient Carbonate Tidalites. In: Davis, R.A. and Dalrymple, R.W., Eds., Principle of Tidal Sedimentology, Springer, 576-609. http://dx.doi.org/10.1007/978-94-007-0123-6_21

[12] Catuneanu, O. (2006) Principles of Sequence Stratigraphy. Elsevier B.V, Italy, 387 p.

[13] Catuneanu, O., Abrea, V., Bhuttacharya, J.P., Blum, M.D., Dalrymple, R.W., Eriksson, P.G., Fielding, C.R., Fisher, W.L., Galloway, W.E., Gibling, M.R., Giles, K.A., Holbrook, J.M., Jordan, R., Kendall, C.G.S.T.C., Macurda, B., Martinsen, O.J., Miall, A.D., Neal, J.E., Nummedal, D., Pomar, L., Posamentier, H.W., Pratt, B.R., Sarg, J.F., Shanley, K.W., Steel, R.J., Strasser, A., Tucker and M.E. and Winker, C. (2009) Towards the Standardization of Sequence Stratigraphy. Elsevier B.V, Earth-Science Reviews, 92, 1-33. http://dx.doi.org/10.1016/j.earscirev.2008.10.003

[14] Catuneanu, O., Galloway, W.E., Kendall, C.G.S.T.C., Miall, A.D., Posamentier, H.W., Strasser, A. and Tucker, M.E. (2011) Sequence Stratigraphy: Methodology and Nomenclature. Newsletters on Stratigraphy, 44, 173-245. http://dx.doi.org/10.1127/0078-0421/2011/0011

[15] Snedden, J.W. and Liu, C. (2010) A Compilation of Phanerozoic Sea-Level Change, Coastal Onlaps and Recommended Sequence Designation. Search and Discovery Article 40594, AAPG.

[16] Haq, B.U. and Shutter, S.R. (2008) A Chronology of Paleozoic Sea-Level Changes. Science, 322, 64-68. http://dx.doi.org/10.1126/science.1161648

[17] Haq, B.U. and Al-Qahtani, A.M. (2005) Phanerozoic Cycles Change on Arabian Platform. GeoArabia, 10, $127-160$.

[18] Bendias, D., Koehrer, B., Obermaier, M. and Aigner, T. (2013) Mid-Permian Khuff Sequence KS6: Paleo Relief-Influenced Facies and Sequences Patterns in the Lower Khuff Time-Equivalent Strata, Oman Mountains, Sultanate of Oman. GeoArabia, 18, 135-178.

[19] Koehrer, B., Aigner, T., Forke, H. and Pöppelreiter, M. (2012) Middle to Upper Khuff (Sequences KS1 to KS4) Outcrop Equivalents in the Oman Mountains: Grainstone Architecture on a Sub Regional Scale. GeoArabia, 17, 59-105.

[20] Koehrer, B., Zeller, M., Aigner, T., Pöppelreiter, M., Milory, P., Forke, H. and Al-Kindi, S. (2010) Facies and Stratigraphic Framework of a Khuff Outcrop Equivalent: Saiq and Mahil Formations, Al Jabal al-Akhdar, Sultanate of Oman. GeoArabia, 15, 91-156.

[21] Shen, S.Z., Schnider, J.W., Angiolini, L. and Henderson, C.M. (2013) The International Permian Time Scale: March 2013 Updated. In: Lucas, S.G., et al., Eds., The Carboniferous-Permian Transition, Museum of Natural History and Science, New Mexico, Bulletin 60, 411-416. 
[22] Gradstein, F.M., Ogg, J.C. and Smith, A.G. (2004) A Geological Time Scale. Cambridge University Press, New York.

[23] Sharland, P.R., Archer, R., Casey, D.M., Davies, R.B., Hall, S.H., Heward, A.P., Hourbury, A.D. and Simmons, M.D. (2001) Arabian Plate Sequence Stratigraphy. GeoArabia Special Publication 2, Gulf PetroLink, 371 p.

[24] Simmons, M.D., Sharland, P.R., Casey, D.M., Davies, R.B. and Sutcliffe, O.E. (2007) Arabian Plate Sequence Stratigraphy: Potential Implications for Global Chronostratigraphy. GeoArabia, 12, 101-130.

[25] Lotfpour, M., Adabi, M.H., Sadeghi, A. and Moallemi, S.A. (2006) Sedimentary Environment and Sequence Stratigraphy of Dalan Formation in Zagros Area. Tehran University Science Journal, 31, 199-228. (In Persian)

[26] Aleali, M., Rahimpour-Bonab, H., Moussavi-Harami, R. and Jahani, D. (2013) Environmental and Sequence Stratigraphic Implications of Anhydrite Textures: A Case Study from Lower Triassic of Central Persian Gulf. Journal of Asian Earth Science, 75, 110-125. http://dx.doi.org/10.1016/j.jseaes.2013.07.017

[27] Teymourzadeh, H., Vaziri, S.H., Jahani, D., Kohansal Ghadimvand, N. and Yahyaei, A. (2014) Exploration Characteristics and Lithostratigraphy of the Kangan and Upper Dalan Formations in Lavan Gas Field, Northen Persian Gulf. Academic Research Part A, 6, 311-320.

[28] Jahani, D., Kohansal Ghadimvand, N. and Mohammad-Jafari, P. (2012) Anhydrite Fabrics in Kangan Formation (Lower Triassic) in Fars and Zagros Sub-Basins. Journal of Salt, 1, 13-18. (In Persian)

[29] Zamannejad, A., Jahani, D., Lotfpour, M. and Movahed, B. (2013) Mixed Evaporite/Carbonate Characteristics of the Triassic Kangan Formation, Offshore Area, Persian Gulf. Revista Mexicana de Ciencias Geológicas, 30, 540-551.

[30] Tucker, M.E. and Wright, V.P. (1990) Carbonate Sedimentology. Blackwell Publishing Company, Cornwall. http://dx.doi.org/10.1002/9781444314175

[31] Alsharhan, A.S. and Kendall, C.G.S.T.C. (2002) Holocene Coastal Carbonate and Evaporites of the southern Arabian Gulf and Their Ancient Analogues. Earth Science Reviews, 61, 191-243. http://dx.doi.org/10.1016/S0012-8252(02)00110-1

[32] Gundogan, I., Mehmet, O. and Depçi, T. (2005) Sedimentology, Petrography, and Diagenesis of Eocene-Oligocene Evaporites: The Tuzhisar Formation, SW Sivas Basin, Turkey. Journal of Asian Earth Science, 25, 791-803. http://dx.doi.org/10.1016/j.jseaes.2004.08.002

[33] Steinhoff, I. and Strohmenger, C. (1996) Zechstein 2 Carbonate Platform Subfacies and Grain-Type Distribution (Upper Permian, Northwest Germany). Facies, 35, 105-132. http://dx.doi.org/10.1007/BF02536959

[34] Khalifa, M.A. (2004) Lithofacies, Diagenesis and Cyclicity of the "Lower Member" of the Khuff Formation (Late Permian), Al Qasim Province, Saudi Arabia. Journal of Asian Earth Sciences, 25, 719-734. http://dx.doi.org/10.1016/j.jseaes.2004.05.008

[35] Sadeghi, M., Rashidi, K. and Shabanian, R. (2015) Introducing the Calcareous Algae of Permian Dasyclads and Gymnocodiacean Family, Pir-Eshagh Section, South Jolfa, a Report of Tabasoporella sp. from Dasyclad Family in Northwestern Iran. Geosciences, 24, 55-66. (In Persian)

[36] Madi, A., Savard, M.M., Bourque, P.A. and Chi, G. (2000) Hydrocarbon Potential of the Mississippian Carbonate Platform, Bechar Basin. Algerian Sahara, 84, 266-287.

[37] Riding, R. (1991) Calcified Cyanobacteria. In: Riding, R., Ed., Calcareous Algae and Stromatolites, Springer, Berlin, 55-87. http://dx.doi.org/10.1007/978-3-642-52335-9_3

[38] Karimi, H., Ghadimvand, N.K. and Kangazian, A. (2015) Sedimentary Environment and Sequence Stratigraphy of the Kangan Formation in Kish Gas Field (Kish Well A1 Subsurface Section). Indian Journal of Science and Technology, 8, 655-663. http://dx.doi.org/10.17485/ijst/2015/v8i7/62853

[39] Strasser, A. (1984) Black-Pebble Occurrence and Genesis in Holocene Carbonate Sediments (Florida Keys, Bahamas and Tunisia). Journal of Sedimentary Petrology, 54, 1097-1109. http://dx.doi.org/10.1306/212f856c-2b24-11d7-8648000102c1865d

[40] Smith, A.M. (1995) Paleoenvironmental Interpretation Using Bryozoans. In: Bosence, D.W. and Allison, P.E., Eds., Marine Paleoenvironmental Analysis from Fossils, Geological Society of London, Special Publication, London, No. 83, 231-243. http://dx.doi.org/10.1144/GSL.SP.1995.083.01.11

[41] Madi, A., Bourque, P.A. and Mamet, B.I. (1996) Depth-Related Ecological Zonation of a Carboniferous Carbonate Ramp: Upper Viséan of Béchar Basin, Western Algeria. Facies, 35, 59-80. http://dx.doi.org/10.1007/BF02536957

[42] Calvet, E. and Tucker, M. (1988) Outer Ramp Cycles in the Upper Muschelkalk of the Catalan Basin, Northeast Spain. Sedimentary Geology, 57, 785-798. http://dx.doi.org/10.1016/0037-0738(88)90026-7

[43] Posamentier, H.W. and Allen, G.P. (2000) Siliciclastic Sequence Stratigraphy: Concepts and Applications. SEPM Concepts in Sedimentology and Paleontology Series 7, Society for Sedimentary Geology, Tulsa.

[44] Sharland, P.R., Casey, D.M., Davies, R.B., Simmons, M.D. and Sutcliffe, O.E. (2004) Arabian Plate Sequence Stratigraphy. GeoArabia, 9, 199-214. 
[45] Stampfli, G. (2000) Tethyan Oceans. In: Bozkurt, E., Winchester, J.A. and Piper, J.D.A., Eds., Tectonics and Magmatism in Turkey and the Surrounding Area, Geological Society of London, Special Publication, London, 1-23. http://dx.doi.org/10.1144/gsl.sp.2000.173.01.01

[46] Angiolini, L., Balini, M., Garzanti, E., Nicora, A., Tintori, A., Crasquin, S. and Muttoni, G. (2003) Permian Climatic and Paleogeographic Changes in Northern Gondwana: The Khuff Formation of Interior Oman. Palaeogeography, Palaeoclimatology, Palaeoecology, 191, 269-300. http://dx.doi.org/10.1016/S0031-0182(02)00668-5

[47] Tavakoli, V., Rahimpour-Bonab, H. and Esrafili-Dizaji, B. (2010) Diagenetic Controlled Reservoir Quality of South Pars Gas Field, an Integrated Approach. Comptes Rendus Geosciences, 343, 55-71. http://dx.doi.org/10.1016/j.crte.2010.10.004

[48] Haq, B.U., Hardenbol, J. and Vail, P.R. (1988) Mesozoic and Cenozoic Chronostratigraphy and Cycles of Sea-Level Change: An Integrated Approach. In: Wilgus, C.K., Hastings, B.S., Kendall, C.G.S.C., Posamentier, H.W., Ross, C.A. and Van Wagoner, J.C., Eds., Sea-Level Changes: An Integrated Approach, SEPM Special Publication, Vol. 42, 71-108. http://dx.doi.org/10.2110/pec.88.01.0071

\section{Submit or recommend next manuscript to SCIRP and we will provide best service for you:}

Accepting pre-submission inquiries through Email, Facebook, LinkedIn, Twitter, etc. A wide selection of journals (inclusive of 9 subjects, more than 200 journals)

Providing 24-hour high-quality service

User-friendly online submission system

Fair and swift peer-review system

Efficient typesetting and proofreading procedure

Display of the result of downloads and visits, as well as the number of cited articles

Maximum dissemination of your research work

Submit your manuscript at: http://papersubmission.scirp.org/ 